\title{
PARAMETRIC STUDY ON SLENDER COLUMN FOR FLAT PLATE STRUCTURE
}

\author{
Shinde S. S ${ }^{1}$, Patil P. S \\ ${ }^{1} P G$ Scholar, Department of Civil Engineering, RIT Islampur, Maharashtra, India \\ ${ }^{2}$ Professor, Department of Civil Engineering, RIT Islampur, Maharashtra, India
}

\begin{abstract}
This paper deals with effect of slender column on flat plate structure. The column is called slender if the height of is increased for functional purpose. The study is conducted on 18 flat-plate reinforced cement concrete (RCC) structural models. Among these 18 models, 54 columns at three different locations (i.e. corner, edge and inner columns) are chosen for study. The models are developed using ETABS Software. Parametric study is performed by considering six different height of column ranging from 3048 $\mathrm{mm}$ to $6858 \mathrm{~mm}$, using an increment of $762 \mathrm{~mm}$ along with three slab panels of size $4572 \mathrm{~mm} \times 4572 \mathrm{~mm}, 6096 \mathrm{~mm} \times 6096 \mathrm{~mm}$ and $7620 \mathrm{~mm} \times 7620 \mathrm{~mm}$ with five panels in both ways, considering both gravity and environmental load. The effect of slenderness ratio on load carrying capacity, design load and steel ratio is considered along with this the effect of additional moment due to slender compression member is also taken into account. It is observed that, columns in flat-plate structures are generally very sensitive if they are slender. It is observed that as the column length increases from $5502 \mathrm{~mm}$ and further, the steel ratio suddenly increases and it exceeds maximum allowed. As slenderness ratio increases, ratio of design load to the critical buckling load increases. Also resulting in increase of additional moment, decreasing load carrying capacity of column. This forces the design engineer to study effect of different parameter of the structure while designing high rise flat plate structure.
\end{abstract}

Keywords: Flat Plate Structure, ETABS, Slenderness, Environmental load, design load and buckling load.

\section{INTRODUCTION}

The slender column is one having smaller cross sectional dimensions as compared to its length. In a structure, a slender column has less strength as compared to short column with the same sectional area. Due to this the slender column carries lesser load as compared to the short column. Generally in India the two type of structure is constructed such as beam-column frame structure and flat plat structure including sway \& non sway frame.

Slender columns are those members whose ultimate load carrying capacities are affected by the slenderness effect, which produces additional bending stresses or instability of columns. Therefore, evaluation of a slender column involves consideration of the column length in addition to its cross section. The column having ratio of effective length to its list lateral dimension exceed or equal to 12 according to IS 456-2000 is treated as slender column.

The slender column is developed in multistoried structure due to increasing ground floor height for functional purpose or architectural purpose. On the other hand, the modern trend is towards taller and slender structures.

Flat plate buildings have been damaged on a very large scale, because these structure are analyzed and designed as per IS code. Hence it is required to evaluate actual performance of flat plate structure subjected to dynamic and gravity loads.

\section{MODELLING AND ANALYSIS}

\subsection{Model Development}

ETABS version 9.7.4 is chosen for the parametric study. All the flat-plate models consist of $\mathrm{G}+12$ stories and are of a square shape building with opening at middle. Every floor consists of five panels in each direction and a shear wall at the middle of the building. The foundation for columns and shear walls are assigned as fixed support.

The ground floor is increased from $3048 \mathrm{~mm}$ to $6858 \mathrm{~mm}$ height with an increment of $762 \mathrm{~mm}$ for the parametric study purposes. The other story height is $3048 \mathrm{~mm}$ and kept unchanged in all structures and analysed.

The clear cover of concrete column is $30 \mathrm{~mm}$. The compressive strength of concrete is $25 \mathrm{MPa}$. Strength of steel is $500 \mathrm{MPa}$ and Modulus of Elasticity is 25000 $\left(\mathrm{N} / \mathrm{mm}^{2}\right)$.

\subsection{Problem Statement}

The parametric study of 18 models ( 3 models for each floor panel size having 6 varying column lengths) is done for flat-plate structure with opening at the middle of building with tube shape shear wall of $230 \mathrm{~mm}$ thickness in core of the structure. Following are three cases of slab panel sizes designed by direct design method using IS 456-2000 and all slab depth is safe for shear. 
Table -1: Parameters for parametric study (a)

\begin{tabular}{|c|c|c|c|c|}
\hline Case & $\begin{array}{l}\text { Floor panel } \\
\text { size in } \\
\text { mm@ } \\
\text { opening size } \\
\text { in mm } \mathrm{m} \\
\mathrm{mm} \text {. }\end{array}$ & $\begin{array}{l}\text { Slab } \\
\text { Thick. } \\
\text { in mm }\end{array}$ & $\begin{array}{l}\text { Peri. } \\
\text { beam } \\
\text { size in } \\
\mathrm{mm}\end{array}$ & $\begin{array}{l}\text { Drop panel } \\
\text { size in mm } \\
\text { @ thickness } \\
\text { in } \mathrm{mm}\end{array}$ \\
\hline 1 & $\begin{array}{l}4572 \times 4572 \\
@ 1524 \\
x 1524\end{array}$ & 215 & $\begin{array}{l}230 \quad x \\
500\end{array}$ & $\begin{array}{l}1524 \times 1524 \\
\text { @ } 60\end{array}$ \\
\hline 2 & $\begin{array}{l}6096 @ x \\
6096 @ 3048 \\
x 3048\end{array}$ & 260 & $\begin{array}{ll}380 & x \\
380 & \end{array}$ & $\begin{array}{l}2000 \times 2000 \\
\text { @ } 70\end{array}$ \\
\hline 3 & $\begin{array}{lr}7620 & \mathrm{x} \\
7620 & @ \\
3048 \times & 3048\end{array}$ & 300 & $\begin{array}{l}600 \quad x \\
600\end{array}$ & $\begin{array}{l}2540 \times 2540 \\
\text { @ } 80\end{array}$ \\
\hline
\end{tabular}

Table -2: Parameters for parametric study (a cont...)

\begin{tabular}{|c|c|c|c|}
\hline Cases & $\begin{array}{l}\text { Column } \\
\text { position }\end{array}$ & $\begin{array}{l}\text { Column length } \\
\text { @ ground level } \\
\text { in } \mathrm{mm}\end{array}$ & $\begin{array}{l}\text { Column size } \\
\text { in } \mathrm{mm}\end{array}$ \\
\hline \multirow{3}{*}{$\begin{array}{l}\text { Case } \\
1\end{array}$} & Corner column & $\begin{array}{lrr}3048 \text { to } & 6858 \\
@ & & 762 \\
\text { increment } & \\
\end{array}$ & $300 \times 385$ \\
\hline & Edge column & similar & $385 \times 450$ \\
\hline & Inner column & similar & $450 \times 450$ \\
\hline \multirow{3}{*}{$\begin{array}{l}\text { Case } \\
2\end{array}$} & Corner column & similar & $300 \times 500$ \\
\hline & Edge column & similar & $385 \times 750$ \\
\hline & Inner column & similar & $450 \times 600$ \\
\hline \multirow{3}{*}{$\begin{array}{l}\text { Case } \\
3\end{array}$} & Corner column & similar & $300 \times 650$ \\
\hline & Edge column & similar & $385 \times 1200$ \\
\hline & Inner column & similar & $450 \times 850$ \\
\hline
\end{tabular}

Table -2: Earthquake Parameters (IS1893-2000)

\begin{tabular}{|l|l|l|}
\hline 1 & Dead load on Terrace Floor & $2.5 \mathrm{KN} / \mathrm{m}^{2}$ \\
\hline 2 & live load on Terrace Floor & $1.5 \mathrm{KN} / \mathrm{m}^{2}$ \\
\hline 3 & Dead load on Remaining floor & $1 \mathrm{KN} / \mathrm{m}^{2}$ \\
\hline 4 & live load on Remaining floor & $2.5 \mathrm{KN} / \mathrm{m}^{2}$ \\
\hline 5 & Parapet Wall Load on beam & $5.52 \mathrm{KN} / \mathrm{m}$ \\
\hline 6 & Wall Load on Remaining beam & $11.72 \mathrm{KN} / \mathrm{m}$ \\
\hline 7 & Basic wind speed & $44 \mathrm{~m} / \mathrm{sec}$ \\
\hline 8 & Type of Structure & SMRF \\
\hline 9 & Seismic Zone & III \\
\hline 10 & Type of Soil & Medium soil \\
\hline 11 & Damping & $5 \%$ \\
\hline 12 & Zone factor $(Z)$ & 0.16 \\
\hline 13 & Importance factor & 1 \\
\hline 14 & Response Reduction Factor & $5(\mathrm{SMRF})$ \\
\hline
\end{tabular}

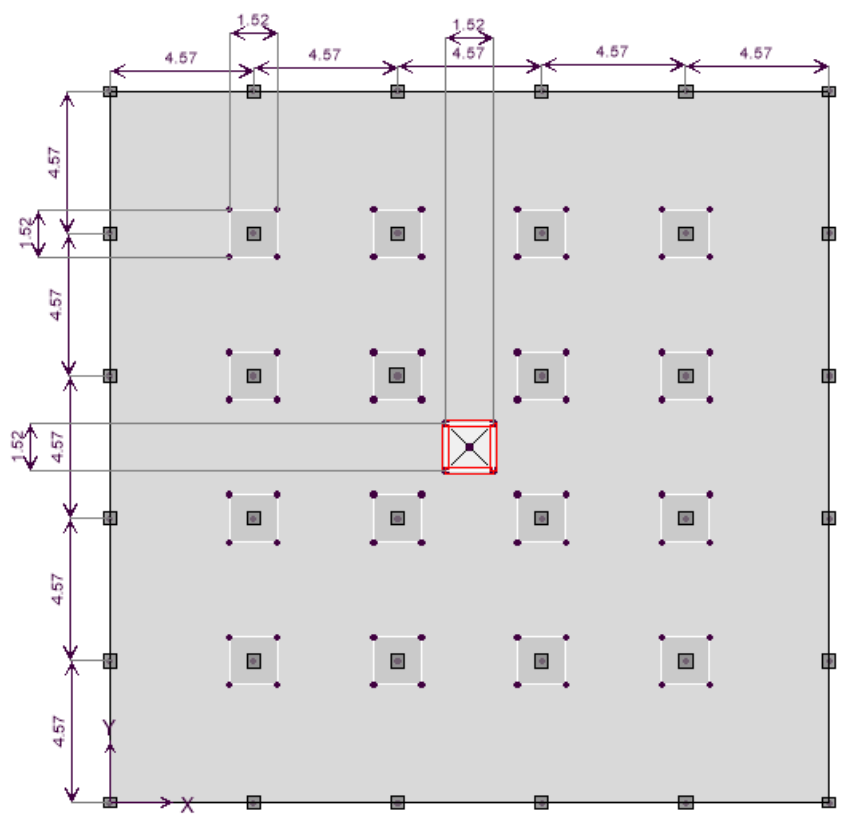

Fig -1: Plan of G+12 storied flat slabs building of case 1 consider for study in ETABS

\subsection{Load Combination considered for Study}

Following load combinations are considered for study.
1) $1.5(\mathrm{DL}+\mathrm{LL})$
2) $1.5(\mathrm{DL} \pm$ Spect 1$)$
3) 1.2 DL $\pm 0.3 \mathrm{LL} \pm 1.2$ Spect 1
4) $1.5 \mathrm{DL} \pm 1.5 \mathrm{WLX}$
5) $1.2(\mathrm{DL} \pm \mathrm{LL} \pm \mathrm{WLX})$
6) $0.9 \mathrm{DL} \pm 1.5$ Spect 1
7) $0.9 \mathrm{DL} \pm 1.5 \mathrm{WLX}$

\section{VALIDATION OF RESULTS}

For the validation of results, a G+12 storied flat slab building has been analyzed by the IS 1893-2000 code method manually and using ETABS v 9.7.4 software. The dynamic analysis is carried out for case 1 with floor height of size $3048 \mathrm{~mm}$ for the entire floor. All parameters are defined in Table 1 and Table 2. The time period of $2.662 \mathrm{sec}$. (from ETABS) is used for manual calculation.

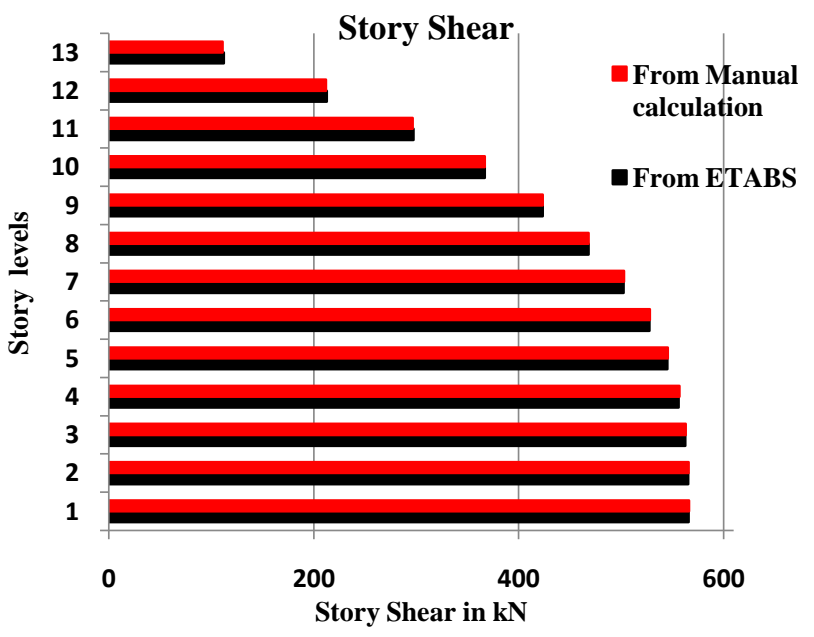

Chart -1: Variations of story shear for case 1 
Table -3: Validation by software result

\begin{tabular}{|l|l|l|l|}
\hline Parameters & $\begin{array}{l}\text { From } \\
\text { ETABS }\end{array}$ & $\begin{array}{l}\text { From manual } \\
\text { calculation }\end{array}$ & $\begin{array}{l}\% \text { of } \\
\text { Error }\end{array}$ \\
\hline $\begin{array}{l}\text { Base Shear in } \\
\mathrm{kN}\end{array}$ & 566.15 & 566.4974 & 0.06 \\
\hline $\begin{array}{l}\text { Total Seismic } \\
\text { Weight of } \\
\text { Structure in kN }\end{array}$ & $\begin{array}{l}69260.5 \\
6\end{array}$ & 69302.21 & 0.06 \\
\hline
\end{tabular}

Result of Base shear obtained from manual calculation and from ETABS v9.7.4 is $566.4974 \mathrm{KN}$ and $566.15 \mathrm{KN}$ respectively. The percentage difference is $0.06 \%$, hence results of software is valid.

\section{RESULT AND DISSCUSTION}

\subsection{Effect on Column}

Chart no. 2, 3,5,6,8 and 9 shows result of critical buckling load $\left(\mathrm{P}_{\mathrm{c}}\right)$, design load $\left(\mathrm{P}_{\mathrm{u}}\right)$, ratio of design load to the critical buckling load $\left(\mathrm{P}_{\mathrm{u}} / \mathrm{P}_{\mathrm{c}}\right)$, and slenderness ratio for different cases. The end conditions, effectively held in position and restrained against rotation at one end and restrained against rotation but not held in position at other is provided, this end condition is considered for study in which effective length of column is taken as $1.2 \times \mathrm{L}$.

The buckling load is calculate from following equation, where $\mathrm{k}$ is effective length factor, $\mathrm{l}$ is length of compression member, $\mathrm{E}$ is the elastic modulus of column, $\mathrm{I}$ is the minimum moment of inertia.

$$
\mathrm{P}_{\mathrm{c}}=\frac{\pi^{2} E I}{(k l)^{2}}
$$

The slenderness ratio is calculated by following equation,

$$
\lambda=\frac{l_{e x}}{D}
$$

Where, $\lambda$ is slenderness ratio, $1_{\mathrm{ex}}$ is effective length in respect of the major axis, and $\mathrm{D}$ is the depth in respect of the major axis,

\subsubsection{Corner Column}

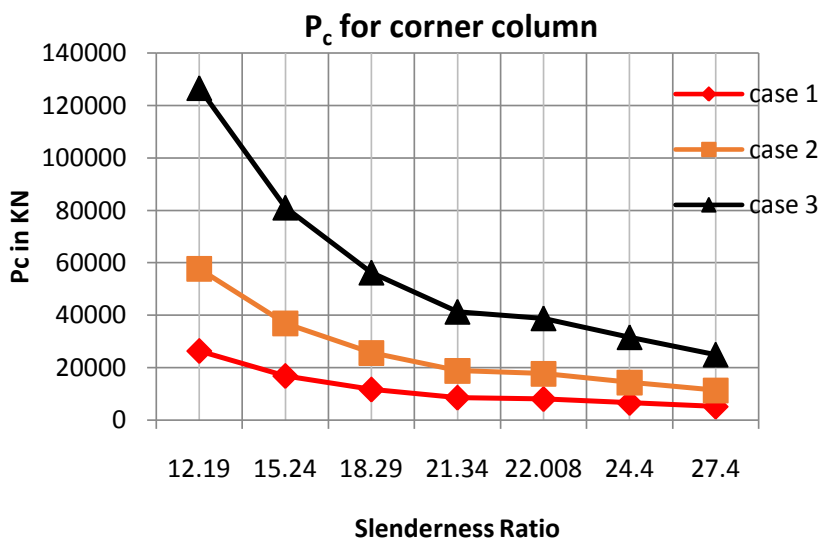

Chart-2: $\mathrm{P}_{\mathrm{c}}$ load variation for corner column for all cases

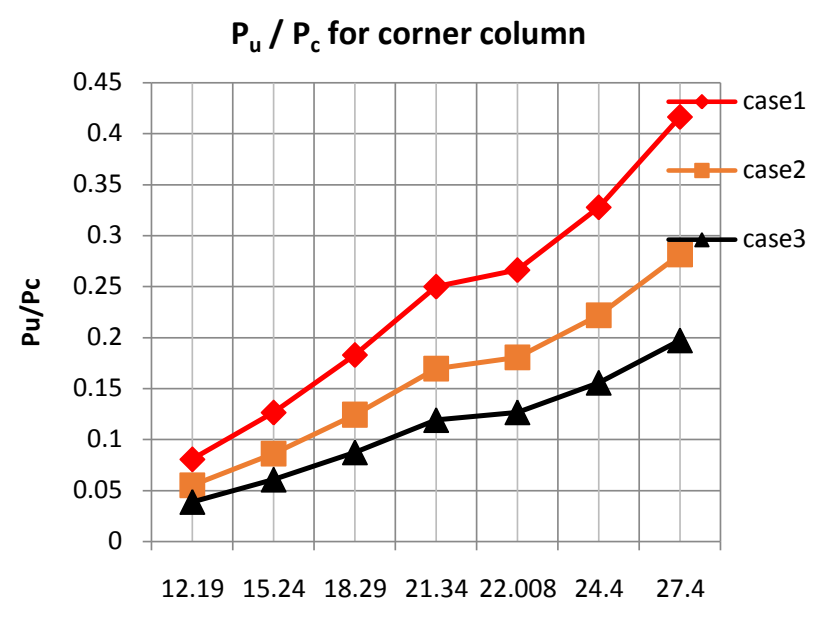

Slenderness Ratio

Chart-3: variation of $\mathrm{P}_{\mathrm{u}} / \mathrm{P}_{\mathrm{c}}$ in corner column for all cases

According to (IS 456cl.39.7.1), the design of slender compression members shall be based on the forces and the moments determined from an analysis of structure, including the effect of deflection on moments and forces.

When the effect of deflections is not taken into account in the analysis, additional moment shall be taken into account in the appropriate direction. Following chart 4 shows additional moment in corner column due to slender effect from ETABS.

\section{Additional moments in corner column}

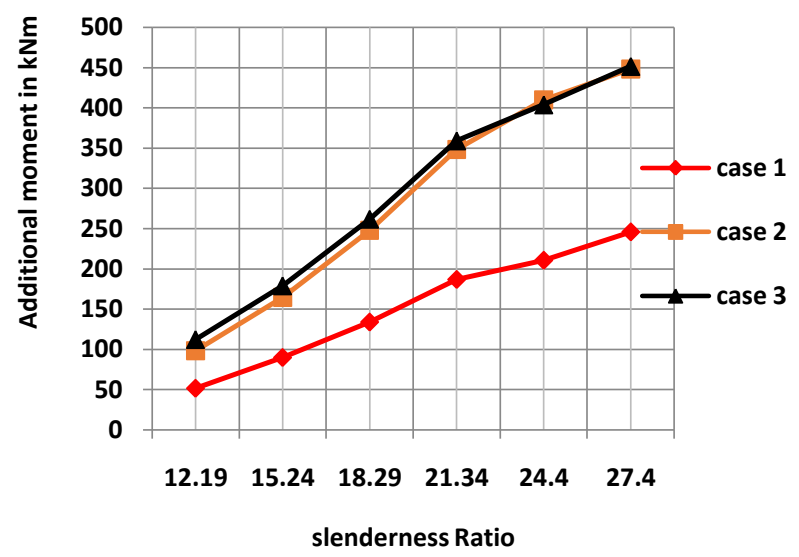

Chart-4: Additional moment in corner column for all cases

\section{Closure}

For all cases, corner column fails when slenderness ratio exceeds 22 and shows slender behavior while $\mathrm{P}_{\mathrm{u}}$ increases about $29 \%$ of $\mathrm{P}_{c} . \mathrm{P}_{c}$ decreased by $27.5 \%$ when slenderness ratio increases about $14.91 \%$ with $\mathrm{P}_{\mathrm{u}}$ increased about $0.25 \%$ for all cases. When slenderness ratio increases by $14.91 \%$, the additional moment due to slender compression member is increases by $24.90 \%$. 


\subsubsection{Edge Column}

The Edge column fails when slenderness ratio exceeds 17.15 while slenderness limit from IS 456 is given as 23.1.The column shows slender behavior when $\mathrm{P}_{\mathrm{u}}$ increases about $29.22 \%$ of $\mathrm{P}_{\mathrm{c}} . \mathrm{P}_{\mathrm{c}}$ decreased about $27.5 \%$ when slenderness ratio increases about $14.91 \%$ with $\mathrm{Pu}$ increased about $0.12 \%$ for all cases. Following chart shows variation of $\mathrm{P}_{\mathrm{u}}$ and $\mathrm{P}_{\mathrm{c}}$ on edge column.

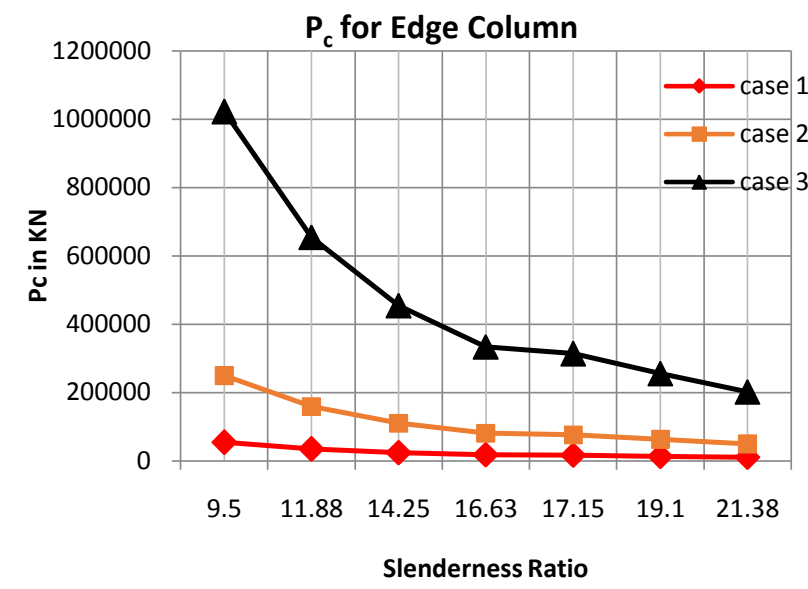

Chart-5: $\mathrm{P}_{\mathrm{c}}$ load variation in edge column for all cases

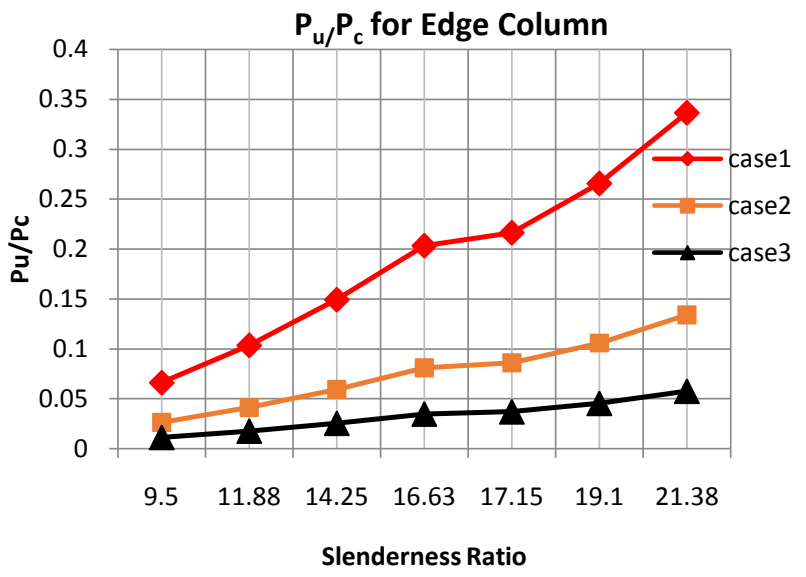

Chart-6: variation of $\mathrm{P}_{\mathrm{u}} / \mathrm{P}_{\mathrm{c}}$ in edge column for all cases

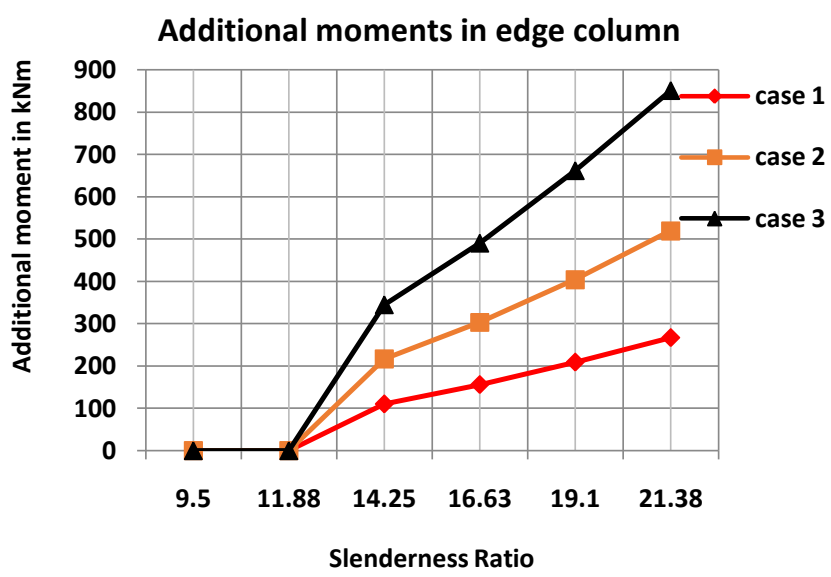

Chart-7: Additional moment in edge column for all cases
For slender edge column, the slenderness ratio increases by $12.64 \%$, the additional moment due to slender compression member is increases by $25.534 \%$.

\subsubsection{Inner Column}

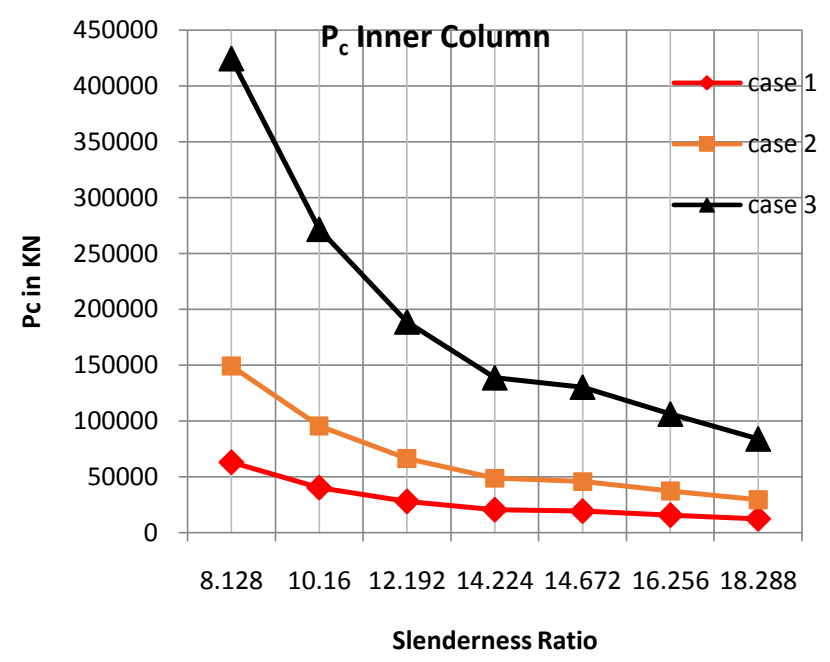

Chart-8: $\mathrm{P}_{\mathrm{c}}$ load variation in inner column for all cases

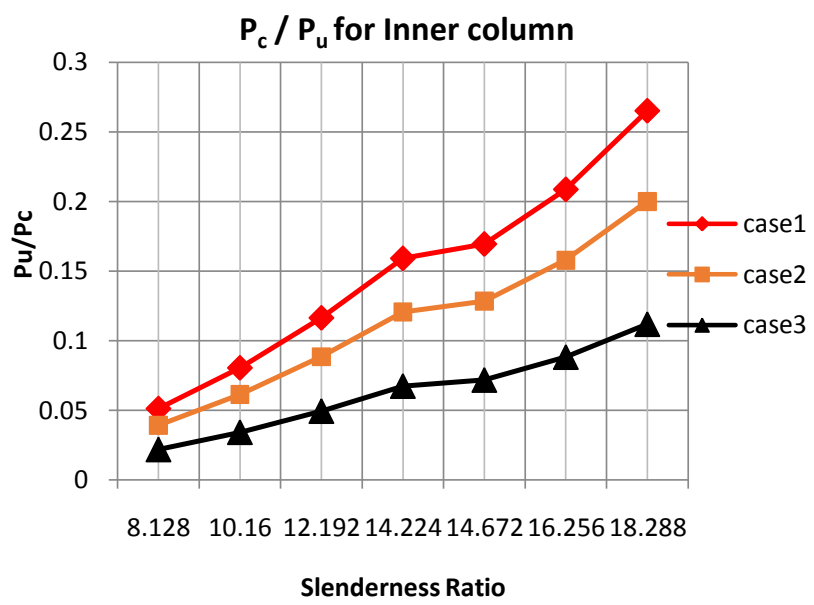

Chart-9: variation of $\mathrm{P}_{\mathrm{u}} / \mathrm{P}_{\mathrm{c}}$ in inner column for all cases

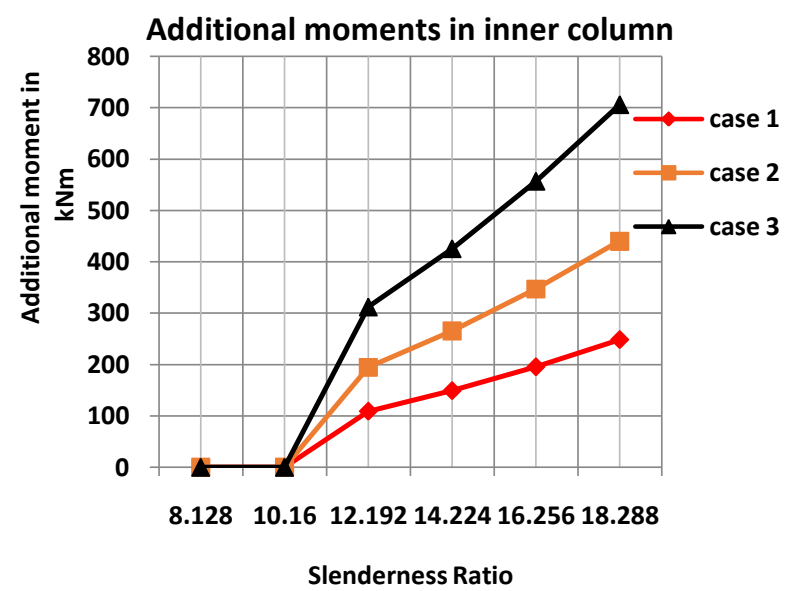

Chart-10: Additional moment in inner column for all cases 


\section{Closure}

For case 3, inner columns fail when slenderness ratio exceeds 16.256. The column shows slender behavior when $\mathrm{P}_{\mathrm{u}}$ increases about $26.26 \%$ of $\mathrm{P}_{\mathrm{c}}$. When slenderness ratio increases about $14.91 \%, \mathrm{P}_{c}$ decreased about $27.5 \%$ and $\mathrm{P}_{\mathrm{u}}$ increased about $0.8 \%$ for all cases. For slender inner column, the slenderness ratio increases by $12.64 \%$, the additional moment due to slender compression member is increases by $23.845 \%$.An inner column for case 3 needs more attention than for same column in case1.

\section{CONCLUSION}

From the research work done as per above, following conclusion can be drawn, Design load increases about $30 \%$ of critical buckling load for all panels. The buckling load decreases by $27.5 \%$ along with increase in additional moments by $25 \%$, when slenderness ratio increases about $14.91 \%$.Thus in flat plate structure, corner and edge columns are more sensitive to slender effect than that of inner column. A corner column for all case needs more attention than edge and inner column.

\section{REFERENCES}

\section{Journals:}

[1]. Hossain Mohammad., Hossain Tahsin.(2014), 'Finite Element Approach to Perform Parametric Study on Slender Column for Flat Plate Structure', International Journal of Civil and Structural Engineering Research, ISSN 23487607, vol. 2, pp.15-24.

[2]. Micallef K., Sagaseta J., et al.(2014), 'Assessing Punching Shear Failure in Reinforced Concrete Flat Slab subjected to Localized Impact Loading', International Journal of Impact Engineering, vol.71, pp.17-33.

[3]. P M B Raj Kiran Nanduri, Dr. B. Dean Kumar, et al.(2012), 'Comparative Study of Wind Load Analysis of Flat Plate Multistoried Frames With and Without Reinforced Concrete Infilled Walls', International Journal of Emerging Technology and Advanced Engineering, ISSN 2250-2459, vol. 2, pp.177-182.

[4]. Sagaseta J., Tassinari L., et al. (2014), 'Punching of Flat Slab supported on Rectangular Column', Engineering Structure, vol. 77, pp. 17-33.

[5]. Silva N. F., et al. (2013), 'Experimental and Parametric 3D nonlinear Finite Element Analysis on Punching of Flat Slab with Orthogonal Reinforcement', Engineering Structure, vol.48, pp. 442-457.

[6]. Thomas H.,Wallace J., et al. (2004), 'Shake Table Tests of Reinforced Concrete Flat Plate Frames and PostTensioned Flat Plate Frames', $13^{\text {th }}$ World Conference on Earthquake Engineering Vancouver, B.C., Canada, pp. 1119.

[7]. Wimbadi Iman, Winoto Paulus. (2010), 'Slenderness Study of Square Reinforcement Concrete Column with Software', International Seminar on Applied Technology, Science and Arts, Surabaya .ISSN 2086-1931, pp. 1-4.

\section{Codes:}

[8]. IS 456-2000: Indian Standard Plain and Reinforced Concrete - Code of Practice. Fourth Revision.

[9]. IS1893 (Part 1) 2002: Indian Standard Criteria for Earthquake Resistant Design Of Structures. Part 1 General Provision and Buildings. Fifth Revision.

\section{Books:}

[10]. Punmia B. C. et al. (2006), 'RCC Designs, Reinforced concrete structures', Tenth edition, Lakshmi Publication. [11]. Shrikhande M. and Agrawal P. (2006), 'Earthquake Resistance Design of Structure', First Revised Edition. New Delhi: PHI Learning Private Limited.

\section{BIOGRAPHIES}

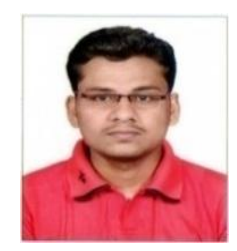

Shinde S. S., P.G. (Civil Structures) Scholar, Department of Civil Engineering, RIT Islampur, Sangli, Maharashtra, India Email: sudhirshinde750@gmail.com

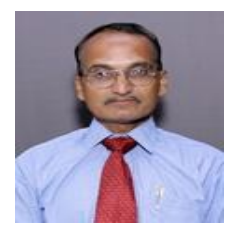

Patil P. S., Professor, Department of Civil Engineering, RIT Islampur, Sangli, Maharashtra, India. Email:pandurang.patil@ ritindia.edu 